\section{Chronic hydroxychloroquine/chloroquine exposure for connective tissue diseases and risk of Alzheimer's disease}

I have read with interest the article by Fardet $e t$ a ${ }^{1}$ regarding chronic hydroxychloroquine/chloroquine exposure for connective tissue diseases and risk of Alzheimer's disease. This populationbased cohort study reported that people who had been chronically exposed to hydroxychloroquine/chloroquine were not at a higher risk of Alzheimer's disease than the control individuals. However, the manuscript has some issues. The results reported by Fardet $e t$ al differ from those of another retrospective case-control study ${ }^{2}$ which demonstrated that patients with rheumatoid arthritis who used conventional synthetic disease-modifying antirheumatic drugs (csDMARDs) including hydroxychloroquine showed a significant association with dementia. First, the risk of confounding may be significant in observational studies, and statistical adjustment for confounders in observational studies may not entirely resolve these problems. Second, the results from observational studies might be spurious due to some types of bias, such as reporting and recall biases. Considering the lack of evidence from randomised controlled trials (RCTs), the conclusions by Fardet et al that hydroxychloroquine/chloroquine do not confer protection against the development of Alzheimer's disease and those by Chou et al ${ }^{2}$ that csDMARD use increases the risk of Alzheimer's disease may be overstated or risky. ${ }^{3}$ The antimalarial drugs, hydroxychloroquine and chloroquine, have well-documented, anti-inflammatory activity and effectively suppress microglial neurotoxicity induced by $\beta$-amyloid protein. ${ }^{4}$ Currently, no RCTs have examined the role of hydroxychloroquine/chloroquine in preventing Alzheimer's disease. Whether hydroxychloroquine/chloroquine increases or decreases the development of Alzheimer's disease cannot yet be confidently stated. With respect to the divergent results from observational studies, well-designed RCTs are required to adequately address the complex problem about the relationship between hydroxychloroquine/chloroquine use and Alzheimer's disease risk.
Young Ho Lee

Correspondence to Professor Young Ho Lee, Department of Rheumatology, Korea University College of Medicine, Seoul 02841, Korea; lyhcgh@korea.ac.kr

Handling editor Josef S Smolen

Competing interests None declared.

Patient consent Not required.

Provenance and peer review Not commissioned; internally peer reviewed.

(c) Author(s) (or their employer(s)) 2018. No commercial re-use. See rights and permissions. Published by BMJ.

$$
\text { D) Check for updates }
$$

To cite Lee YH. Ann Rheum Dis 2019;78:e137.

Received 27 September 2018

Accepted 29 September 2018

Published Online First 18 October 2018

\section{GLinked}

- http://dx.doi.org/10.1136/annrheumdis-2018-214515

Ann Rheum Dis 2019;78:e137. doi:10.1136/annrheumdis-2018-214494

\section{REFERENCES}

1 Fardet L, Nazareth I, Petersen I. Chronic hydroxychloroquine/chloroquine exposure for connective tissue diseases and risk of Alzheimer's disease: a population-based cohort study. Ann Rheum Dis 2019;78:279-82.

2 Chou MH, Wang JY, Lin CL, et al. DMARD use is associated with a higher risk of dementia in patients with rheumatoid arthritis: a propensity score-matched casecontrol study. Toxicol Appl Pharmacol 2017;334:217-22.

3 Rossouw JE, Anderson GL, Prentice RL, et al. Risks and benefits of estrogen plus progestin in healthy postmenopausal women: principal results from the women's health initiative randomized controlled trial. JAMA 2002;288:321-33.

4 Giulian D. Microglia and the immune pathology of Alzheimer disease. Am J Hum Genet 1999;65:13-18.

5 Fardet L, Petersen I, Nazareth I. Response to: 'Chronic hydroxychloroquine/chloroquine exposure for connective tissue diseases and risk of Alzheimer's disease' by Lee. Ann Rheum Dis 2019;78:e138. 